\title{
Techno-Economic and Environmental Assessment of Power Supply Chain by Using Waste Biomass Gasification in Iceland
}

\author{
Sahar Safarian ${ }^{1} \cdot$ Runar Unnthorsson ${ }^{1} \cdot$ Christiaan Richter $^{1}$ \\ Received: 13 February 2020 / Revised: 5 May 2020 / Accepted: 12 May 2020 \\ (c) Springer Nature Switzerland AG 2020
}

\begin{abstract}
In this paper, technical, economic and environmental assessments are carried out for power supply chain by using timber and wood waste (T\&WW) gasification in Iceland. The Icelandic municipalities were clustered into 35 subgroups based on various number of households/ inhabitants. Different expenses were taken into consideration, like capital, installation engineering, operation and maintenance costs and the interest rate of the investment. Regarding revenues, they come from the electricity sale and the fee paid by the Icelandic municipalities for waste collection and disposal. The economic feasibility was conducted based on the economic indicators of net present value (NPV) and discounted payback period (DPP), bringing together three different scenarios, with interest rates of $8 \%$ for Scenario 1, 10\% for Scenario 2 and 13\% for Scenario 3. The environmental analysis was also performed relied on the environmental impacts of global warming (GWP), acidification (AP) and eutrophication (EP) potentials. The results show that changing the interest rate does not have significant impact on NPV and DPP for all studied scenarios. NPV is positive for the municipalities with more than 150 inhabitants or for a gasification plant with the capability to generate greater than $45 \mathrm{~kW}$. Moreover, electricity generation based on T\&WW gasification would lead to a GWP of 13 tonCO ${ }_{2 \mathrm{eq}}$ (Subgroup 1) to 469 tonCO $\mathrm{Ceq}_{\text {eq }}$ (Subgroup 35), AP of 173.6 tonSO $\mathrm{Seq}_{\text {eq }}$ (Subgroup 1) to 6187.2 tonSO $_{2 \text { eq }}$ (Subgroup 35) and EP potential of 331.9 tonNO $_{3 \mathrm{eq}}$ (Subgroup 1) to 11,827.7 tonNO $\mathrm{Heq}_{\text {eq }}$ (Subgroup 35), yearly.
\end{abstract}

Keywords Waste biomass gasification · Techno-economic analysis $\cdot$ Environmental assessment $\cdot$ Power supply chain . Waste to energy

\section{Introduction}

Waste is a major problem that causes not only serious economic losses, but also significant environmental impacts. Better living standards, tourist streams and economic growth accelerate the waste generation in Iceland. Improper management of wastes has led to increased public concerns about health and environmental impacts. The total amount of municipal solid waste (MSW) in Iceland in 2010 has been estimated to $76 \pm 6$ thousand ton, based on data available from Sorpa, the waste management company in the Capital area. In other words, the annual amount of MSW per capita has been estimated to $222-257 \mathrm{~kg}$ (Sundberg et al. 2010). The amount of MSW produced in 2030 is estimated

Sahar Safarian

sas79@hi.is

1 Faculty of Industrial Engineering, Mechanical Engineering and Computer Science, University of Iceland, Hjardarhagi 6, 107 Reykjavik, Iceland to approximately $100 \pm 7$ thousand ton. Generally $60 \%$ of this amount is organic material which 43,41 and $16 \%$ of that are paper mixed, timber and wood and garden wastes, respectively (Safarian et al. 2020b; Sundberg et al. 2010).

Landfilling and incineration have been the only methods of disposal of solid wastes in Iceland, while most landfill sites have been open dumping areas, which pose serious environmental and social threats. An incinerator in Skutulsfjörður caused carcinogenic and toxic chemicals to be found in meat and milk (Halldorsson et al. 2010). Soil and incinerator-emissions measurements at several sites, including Kirkjubaejarklaustur, reveal emissions 85 times above the EU limit (Niðurstöður úr mælingum á díoxínum í jarðvegi 2011). These problems resulted in the shuttering of several incinerators and the withdrawal of Icelandic meat and milk products (Halldorsson et al. 2010; Safarian and Unnthorsson 2018).

All these problems demonstrated the need to find more responsible alternatives than conventional incineration and landfilling (Mohapatra 2013; Omari et al. 2014). The method 
must be environmentally friendly, low cost and energy efficient and must reduce land use and emissions. These advantages are all found in modern gasification technology. Gasification is an attractive alternative that has recently gained considerable attention, as it disposes of solid waste without landfilling or incineration problems (Brunner et al. 2004; Porteous 2005).

Unlike the relatively uncontrolled combustion occurring in incineration, gasification is a partial oxidation at elevated temperature $\left(600-1700{ }^{\circ} \mathrm{C}\right)$ that converts organic components to a Synthesis Gas (syngas), consisting mainly of $\mathrm{CO}, \mathrm{H}_{2}$, small amount of $\mathrm{CH}_{4}$, minor quantities of different hydrocarbons (tars), inorganic impurities $\left(\mathrm{H}_{2} \mathrm{~S}, \mathrm{HCl}\right.$, $\mathrm{NH}_{3}, \mathrm{HCN}, \mathrm{HF}$, alkalis) and particulates (Ofori-Boateng et al. 2013; Safarian et al. 2019d; Samadi et al. 2019). Air, $\mathrm{O} 2$, steam, $\mathrm{CO}_{2}$ or a mixture of all these can be used as an agent in the gasifier. Air gasification produces a syngas with small lower heating value (LHV) among 4-6 MJ/ $\mathrm{Nm}^{3}$, while oxygen gasification produces a syngas with a medium LHV in the range of $10-20 \mathrm{MJ} / \mathrm{Nm}^{3}$ (Leckner 2015).

Beneficially, MSW gasification can be applied for small/ medium scales that leads to dramatic reduction of some pollutants emission as furans, dioxins, and NOx and the possibility of the utilization of the syngas in high efficiency thermal devices like internal combustion engine and gas turbines (Luz et al. 2015). Hence, waste gasification can be installed as a reliable energy supply technology for places which are far from the central energy networks and require district heat and power systems (Safarian et al. 2019a, 2019c, 2020c).

In this paper, we will explore the potential of timber and wood waste (T\&WW) gasification for energy production in small communities in Iceland (T\&WW is the most existing biomass feedstock in this country). In this way, a comprehensive techno-economic and environmental assessment of T\&WW gasification facilities integrated with electricity generation unit will be directed to propose a sustainable waste to power system adapted with conditions in Iceland.

\section{Material and methods}

\section{Case study description}

Iceland is one of the biggest islands in Europe, 103,000 $\mathrm{m}^{2}$ in area. The population of Iceland is only about 300,000 (2.9 per $\mathrm{m}^{2}$ ). Iceland is therefore one of the most sparsely populated countries in the world. The entire country is divided into regional municipalities that have self-determination and responsibility regarding their own affairs. More than $60 \%$ of the population lives in the capital city area. There are 72 municipalities in Iceland that their population varies from 43 inhabitants in the smallest ones, to more than 126,000 in the biggest. About $55 \%$ of Icelandic municipalities have lower than 1000 residents and $70 \%$ of them occupies lower than 2000 populations. In these kinds of regions where wide grid is not feasible, small-scale gasification integrated with power generation offers a viable option for meeting the electricity needs of the local population (Safarian and Unnthorsson 2018).

In order to have a wide evaluation of the economic feasibility of the installation of gasification facilities for all disparate Icelandic zones, we established 35 subgroups based on various number of households/inhabitants (Table 1). In each subgroup, the study was conducted over hypothetical cases, according to the number of households as each household includes 5 persons.

Organic waste produced from industries, household and services sectors is a valuable source for biofuels production in Iceland. In this way, the Icelandic Environment Agency sets up a national plan to decrease the amount of organic wastes which are landfilled or incinerated for years. The main categories of organic waste that can be used as input feedstock into gasifier are timber and wood waste, garden waste, and paper mixed waste. Safarian et al. (2019a, b, c, d) (Safarian et al. 2019c) showed that among the different gasification systems based on various wastes in Iceland, timber and wood waste is the most beneficial from the performance and availability perspectives.

Timber waste is generally defined as unpainted and painted timber and is produced from construction/demolition work, packaging waste and pallets. The total amount of timber waste in Iceland in 2010 has been estimated to

Table 1 The considered subgroups with the number of household and population

\begin{tabular}{llllll}
\hline Subgroups & Household & Persons & Subgroups & Household & Persons \\
\hline 1 & 10 & 50 & 19 & 190 & 950 \\
2 & 20 & 100 & 20 & 200 & 1000 \\
3 & 30 & 150 & 21 & 210 & 1050 \\
4 & 40 & 200 & 22 & 220 & 1100 \\
5 & 50 & 250 & 23 & 230 & 1150 \\
6 & 60 & 300 & 24 & 240 & 1200 \\
7 & 70 & 350 & 25 & 250 & 1250 \\
8 & 80 & 400 & 26 & 260 & 1300 \\
9 & 90 & 450 & 27 & 270 & 1350 \\
10 & 100 & 500 & 28 & 280 & 1400 \\
11 & 110 & 550 & 29 & 290 & 1450 \\
12 & 120 & 600 & 30 & 300 & 1500 \\
13 & 130 & 650 & 31 & 310 & 1550 \\
14 & 140 & 700 & 32 & 320 & 1600 \\
15 & 150 & 750 & 33 & 330 & 1650 \\
16 & 160 & 800 & 34 & 340 & 1700 \\
17 & 170 & 850 & 35 & 350 & 1750 \\
18 & 180 & 900 & & & \\
\hline
\end{tabular}


around $37 \pm 11$ thousand ton and it has been projected to reach approximately $49 \pm 15$ thousand ton in 2030. Wood waste is also available from forestry, and it has been estimated to nearly 8260 ton/year. Totally, timber and wood waste mainly consist of softwood, with a composition of $45 \%$ cellulose, $22 \%$ hemicellulose and $28 \%$ lignin as well as extractives, acids, salts and minerals. Hence, all produced T\&WW can be considered as potential for syngas production (Sundberg et al. 2010).

\section{Process Description}

The studied system in this paper includes all the process steps from resources to the end product (Fig. 1).

Timber and wood waste is the significant resource entering to the system, and liquid fuel and electricity are also the accessory inputs. The proximate and elemental analyses of T\&WW are shown in Table 2.

Diesel fuel is used in trucks for transportation, and electricity is applied for driving force and heat generation over the process. The electricity production in Iceland is derived from geothermal and hydropower that makes Iceland's main source of clean energy. T\&WW is transferred from the waste fields to pretreatment part that is next to gasification and electricity generation unit. The gasification process consists of drying, pyrolysis, combustion and gasification (Safarianbana et al. 2019). Drying occurs at a temperature $100-150{ }^{\circ} \mathrm{C}$. Typically, the moisture in biomass is among $5-35 \%$ that it is reduced to lower 5\% during drying. Pyrolysis occurs in the range of $200-700{ }^{\circ} \mathrm{C}$; in this step, biomass is heated in the absence of oxygen then its volatile components are vaporized. The volatile vapour consists mainly of $\mathrm{H}_{2}, \mathrm{CO}, \mathrm{CO}_{2}, \mathrm{CH}_{4}$, hydrocarbon gases, tar and steam. Finally, combustion turns up in $700-1500{ }^{\circ} \mathrm{C}$ and gasification occurs between 800 and $1100^{\circ} \mathrm{C}$. In this work, the down draft reactors are considered that operate at atmospheric pressure, to gasify $\mathrm{T} \& \mathrm{WW}$ and air is used as the gasification agent, resulting in $\mathrm{CO}_{2}$ and $\mathrm{H}_{2} \mathrm{O}$, which subsequently undergo reduction upon contact with the char produced from pyrolysis. Reduction yields combustible gases as $\mathrm{H}_{2}, \mathrm{CO}$, and $\mathrm{CH}_{4}$ through a series of reactions (Safarian et al. 2019d). Then the produced syngas enters in internal combustion
Table 2 Ultimate and proximate analyses of timber and wood waste (Freeman et al.)

\begin{tabular}{lc}
\hline Parameters & Value (\%) \\
\hline Proximate analysis (wt\%) & 5.01 \\
Moisture & 93.06 \\
Volatile matter (VM) & 6.38 \\
Fixed carbon (FC) & 0.56 \\
Ash & \\
Ultimate analysis (wt\%_dry basis) & 56.8 \\
$\mathrm{C}$ & 7.28 \\
$\mathrm{H}$ & 0.18 \\
$\mathrm{~N}$ & 0.82 \\
$\mathrm{Cl}$ & 0.07 \\
$\mathrm{~S}$ & 34.29 \\
$\mathrm{O}$ & \\
\hline
\end{tabular}

engine that is modelled as a combustion chamber followed by a gas turbine. The combination of these two modules represents the behaviour of a combustion engine where the reaction with air occurs (Safarian and Bararzadeh 2012; Safarian et al. 2013). The input values and key assumptions are shown in Table 3, we also used from our waste biomass gasification simulation model developed by ASPEN Plus (Safarian et al. 2020a) to have the main values of the downdraft gasifier characteristics, operational parameters and the flue gas composition which are listed in Table 3.

\section{Techno-Economic Assessment}

All prices are expressed in $\mathrm{K} €$ (kilo-euro). In the economic assessment, three scenarios are considered based on different interest rates: 8\% in Scenario 1, 10\% in Scenario 2 and $13 \%$ in Scenario 3. A computer program has been developed to investigate these scenarios for all subgroups shown in Table 1. The model is able to evaluate the economic performance of each one. Cash flow analysis, total cost, Net Present Value (NPV) and Discounted Payback Period (DPP) are standardized financial indicators to assess the profitability of projects. A project is an economically attractive while it has the lowest DPP and the NPV higher than zero. NPV

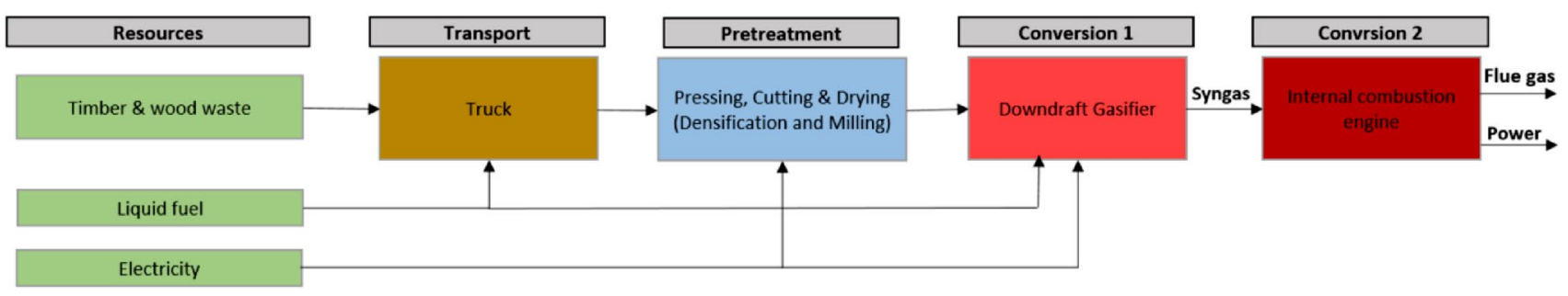

Fig. 1 System boundaries, technologies, energy and material streams 
Table 3 Input values, assumptions, gasifier characteristics, operational parameters and flue gas composition

\begin{tabular}{|c|c|c|c|}
\hline Step & Unit & Amount & Comment \\
\hline \multicolumn{4}{|l|}{ Transport } \\
\hline Distance & $\mathrm{km}$ & 100 & Distance from fields to energy conversion plants \\
\hline Diesel fuel & $\mathrm{L} / \mathrm{km} \cdot \operatorname{ton}_{\mathrm{T} \& \mathrm{WW}}$ & 0.06 & \\
\hline \multicolumn{4}{|l|}{ Preparation } \\
\hline Electricity for pressing \& cutting & $\mathrm{kWh} / \operatorname{ton}_{\mathrm{T} \& \mathrm{WW}}$ & 5.48 & \\
\hline \multicolumn{4}{|l|}{ Conversion 1} \\
\hline Type of gasifier & & & Downdraft fixed bed (autothermal) \\
\hline Gasification agent & & & air \\
\hline Gasification pressure & $\mathrm{kPa}$ & 101.3 & \\
\hline Gasification temperature & ${ }^{\circ} \mathrm{C}$ & 800 & \\
\hline Equivalence Ratio (ER) & - & 0.25 & \\
\hline Specific air mass flow rate consumption & $\mathrm{kg} / \mathrm{kg}_{\mathrm{T} \& \mathrm{WW}}$ & 108 & \\
\hline Unit Fuel oil consumption & $\mathrm{L} / \operatorname{ton}_{\mathrm{T} \& \mathrm{WW}}$ & 0.2 & $\begin{array}{l}\text { It is for start-up of the gasifier. } \text { ton }_{\mathrm{T} \& W W} \text { refers to amount of } \\
\mathrm{T} \& \mathrm{WW} \text { that enters to gasifier after pre-process step }\end{array}$ \\
\hline Unit Electricity consumption & $\mathrm{kWh} / \mathrm{ton}_{\mathrm{T \& WW}}$ & 83 & $\begin{array}{l}\operatorname{ton}_{\mathrm{T} \& W W} \text { refers to amount of } \mathrm{T} \& \mathrm{WW} \text { that enters to gasifier after } \\
\text { pre-process step }\end{array}$ \\
\hline \multicolumn{4}{|l|}{ Conversion 2} \\
\hline Isentropic efficiency of compressor & $\%$ & 90 & \\
\hline Mechanical efficiency of compressor & $\%$ & 99 & \\
\hline Net produced power & $\mathrm{kWh} / \mathrm{yr}$ & $\begin{array}{r}2820.8 \mathrm{MT} \& W W \\
(\mathrm{~kg} / \mathrm{hr})+2293.3\end{array}$ & as functional of mass flow rate of biomass \\
\hline \multicolumn{4}{|c|}{$\begin{array}{l}\text { Specific mass flow rate of flue gas exited } \mathrm{kg} / \mathrm{kg}_{\mathrm{T} \& \mathrm{WW}} \\
\text { from gas turbine }\end{array}$} \\
\hline $\mathrm{CO}$ & & 0.226 & \\
\hline $\mathrm{CO} 2$ & & 1.62 & \\
\hline $\mathrm{H} 2$ & & 0.00247 & \\
\hline $\mathrm{H} 2 \mathrm{O}$ & & 0.645 & \\
\hline $\mathrm{CH} 4$ & & 0 & \\
\hline $\mathrm{N} 2$ & & 5.316 & \\
\hline $\mathrm{O} 2$ & & 0.082 & \\
\hline $\mathrm{S}$ & & 0 & \\
\hline $\mathrm{SO} 2$ & & 0.0013 & \\
\hline $\mathrm{H} 2 \mathrm{~S}$ & & 0 & \\
\hline NH3 & & 0 & \\
\hline NO & & 0.049 & \\
\hline $\mathrm{N} 2 \mathrm{O}$ & & 0 & \\
\hline CL2 & & 0 & \\
\hline HCL & & 0 & \\
\hline $\mathrm{NO} 2$ & & 0.000037 & \\
\hline $\mathrm{H} 2 \mathrm{SO} 4$ & & 0 & \\
\hline NO3 & & 0 & \\
\hline
\end{tabular}

is the difference between the present value of cash inflows and the present value of cash outflows over a period of time and it is calculated based on Eq. (1) (Safarian et al. 2014):

$N P V=\sum_{n=1}^{t} \frac{C F_{n}}{(1+r)^{n}}-C_{c}$ where $\mathrm{CF}_{n}$ is the annual cash flow, being the difference between Revenues $(R)$ and Expenditures $(E)$; Operation and Maintenance Costs $\left(C_{\mathrm{O} \& \mathrm{M}}\right), \mathrm{r}$ is the discount rate $(8 \%$, $10 \%$ and $13 \%$ for Scenarios 1, 2 and 3, respectively); ${ }_{C c}$ is the total capital costs of investment and is the lifetime of the investment (15 years). DPP gives the number of years to break even from undertaking the initial expenditure, by 
discounting future cash flows and recognizing the time value of money and it is calculated according to Eq. (2):

$D P P=\frac{L N\left(\frac{1}{1-\frac{C_{c} \times r}{C F}}\right)}{L N(1+r)}$.

The periodic cash flow, with all the revenues and expenditures, is calculated by considering the incomes from the generated electricity, and the credits for the Waste Treatment Bill (WTB) (Luz et al. 2015). The expenditures also include the ${ }_{C c}$ and $C_{O \& M}$. $C_{c}$ is divided into three categories: hardware price $\left({ }_{C \mathrm{~g}}\right)$, installation cost $\left(25 \%\right.$ of $C_{\mathrm{g}}$ ) and engineering costs, the engineering costs includes engineering and design $\left(13 \%\right.$ of $C_{\mathrm{g}}$ ), purchasing \& construction ( $14 \%$ of $C_{\mathrm{g}}$ ), fuel handling/preparation ( $9 \%$ of $C_{\mathrm{g}}$ ) and electrical/balance of plant (6\% of $C_{\mathrm{g}}$ ) (Porcu et al. 2019; Sara et al. 2016). $C_{\mathrm{g}}$ is the overall price of gasifier system on the basis of various capacities. In this work, we considered $0.75,1.5,2,5,10$, $20,50,100,200,300,400$ and $500 \mathrm{~kW}$ for the small-scale existing gasifiers capacities and extracted their prices from various companies (Fig. 2) (Chongqing Fengyu Electric Co. 2019; GreenVinci Biomass Energy Co. 2019; Labs 2019; Qingdao Kexin New Energy Technology.Co. 2019; Shandong Rotex Machinery. 2019; Tiger Machinery Group Co. 2019).

The whole yearly $C_{O \& M}$ can be determined by the sum of the costs for the maintenance cost $\left(2 \%\right.$ of $\left.{ }_{C c}\right)$, insurance and tax (2\% of $C_{C c}$ ), waste disposal (15\% of $C_{C c}$ ), electricity cost, liquid fuel cost and personnel cost. Electricity costs are calculated based on electricity consumers and liquid fuel costs are estimated for fuel consumers with $7000 \mathrm{~h} /$ year of plant availability (Porcu et al. 2019; Sara et al. 2016). The unitary cost of electrical and fuel energies supplied in Iceland are equal to $0.03 \$ / \mathrm{kWh}$ and $1.08 \$ /$ lit $(0.91 € / \$$ as conversion rate) (Safarian and Unnthorsson 2018). Personnel cost includes annual labour, cost. A total of two employees were assumed for plant operation management (1 person/

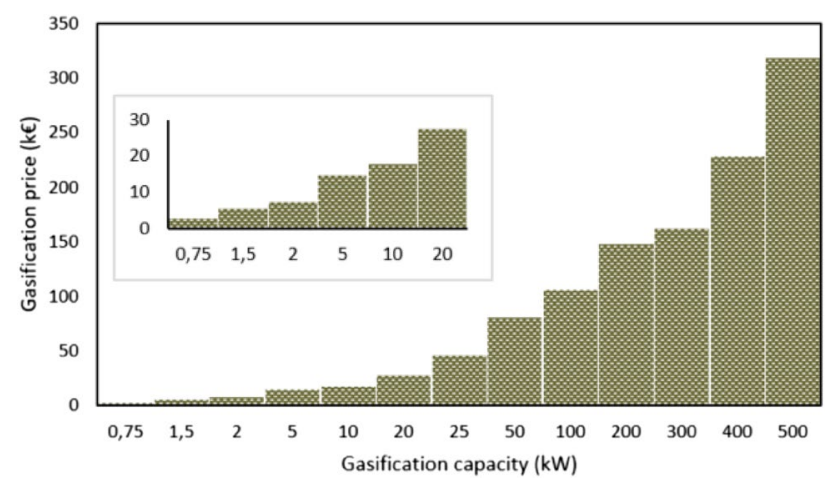

Fig. 2 Gasifier prices for different capacities shift and 2 shifts/day), with a yearly cost of $60,000 € /$ year per person in Iceland.

In relation to revenues, the selling price of electricity to normal households and small businesses in Iceland is about 124.69 \$/MWh (Orkusetur 2019). Hence, the sale price of the generated electricity based on waste gasification was considered at $109.89 \$ / \mathrm{MWh}(100 € / \mathrm{MWh})$ in our work. Moreover, The Icelandic municipalities pay a fee (WTB) by weight, to the private companies, for the collection and disposal the MSW in sanitary landfills. The WTB for collection and disposal of the MSW varies from 90-170 $€ /$ ton through over Iceland. The highest amout is related to Vestmannaeyjar, an archipelago off Iceland's south coast with $111 \mathrm{~km}$ distance from Reykjavik (the Capital of Iceland). All produced waste in Vestmannaeyjar need to be collected and transferred to other Icelandic municipalities for disposal. Hence, WTB for this area is in the top due to geographical conditions and expensive transportation. In this work, a mean value of $130 € /$ ton is used.

\section{Environmental Assessment}

Assessment of the environmental impacts of projects involves evaluating and providing information on the probable effects of specific undertakings on the environment. The environmental indicators studied in this work are global warming (GWP), acidification (AP) and eutrophication (EP) potentials. GWP concentrates on greenhouse gas emissions (GHG) including $\mathrm{CO}_{2}, \mathrm{CH}_{4}$ and $\mathrm{NO}_{2}$ that trap heat through emitting radiation in the atmosphere (Safarian et al. 2018, 2019b). Acidification is also an environmental problem caused by acidified streams and soil due to anthropogenic air pollutants of $\mathrm{SO}_{2}, \mathrm{NH}_{3}, \mathrm{H}_{2} \mathrm{SO}_{4}, \mathrm{H}_{2} \mathrm{~S}, \mathrm{HCL}, \mathrm{SO}_{3}$ and $\mathrm{NO}_{x}$. The main substances with eutrophication impacts are also $\mathrm{NO}_{\mathrm{x}}, \mathrm{NH}_{3}, \mathrm{~N}_{2}$, and $\mathrm{NO}_{3}$ in the case of air. The environmental assessment methods applied in this paper are based on IPCC 2007 and other research works in this field (Nguyen et al. 2013; Paengjuntuek et al. 2015). The GWP, AP and EP factors for key input to the system are summarized in Table 4 (Nguyen et al. 2013; Safarian and Unnthorsson 2018).

\section{Results and Discussion}

\section{Technical Performance}

The calculations performed in this paper show that it is beneficial technically and energetically to produce electrical power from the waste biomass downdraft gasification integrated with power generation. Whether this technology can be successfully applied for the purpose of electricity distribution in small municipalities geographically isolated depends on economic and environmental considerations. 
Table 4 GWP, AP and EP factors for different inputs (Nguyen et al. 2013; Safarian and Unnthorsson 2018)

\begin{tabular}{lllll}
\hline Input & Unit & $\begin{array}{l}\mathrm{GWP} \text { factor } \\
\left(\mathrm{kgCO}_{2 \mathrm{eq}} / \mathrm{unit}\right)\end{array}$ & $\begin{array}{l}\mathrm{AP} \text { factor } \\
\left(\mathrm{gSO}_{2 \mathrm{eq}} / \mathrm{unit}\right)\end{array}$ & $\begin{array}{l}\mathrm{EP} \text { factor } \\
\left(\mathrm{gNO}_{3 \mathrm{eq}} /\right. \\
\text { unit })\end{array}$ \\
\hline Electricity generated by geothermal & $\mathrm{kWh}$ & 0.058 & 1.95 & 2.8 \\
Transport by truck & ton.km & 0.3 & 2.1 & 4.2 \\
Liquid fuel used in gasifier & lit & 2.76 & 10.5 & 21 \\
\hline
\end{tabular}

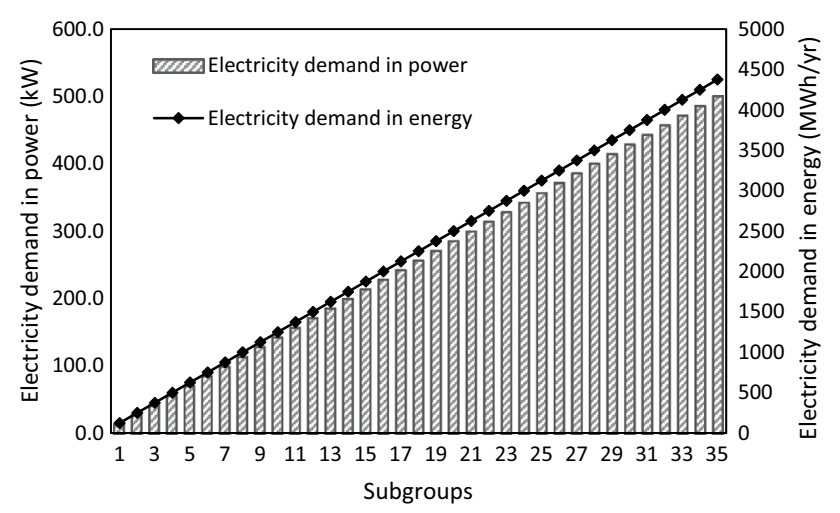

Fig. 3 Electrical energy and power demand for each subgroup

The yearly electricity consumption per capita in the household sector in Iceland is around 2.5 MWh per capita. Based on these data, Iceland occupies the fourth place in electricity consumption in the world (Norway, Sweden and Finland have the first, second and third statues, respectively) (explained 2019). By using these data, the yearly electricity consumption and power demand for each subgroup are calculated and shown in Fig. 3. Obviously, as the population grows, energy demand also increases. Power demand varies form $14.3 \mathrm{~kW}$ for the first subgroup with 50 persons (10 households) to $499,4 \mathrm{~kW}$ for the last one with 1750 persons (350 households).

By considering the demanded power for each subgroup and existing gasifiers capacities (Sect. 2.3), the required gasifiers capacities which need to be installed for each case have been extracted and depicted in Fig. 4. As a constraint, more than two gasifiers have not been taking in account for each subgroup. For example, one gasifier with $20 \mathrm{~kW}$ capacity has been selected to satisfy $14.3 \mathrm{~kW}$ as the requested power for the first subgroup. However, for the second subgroup, two gasifiers with 5 and $25 \mathrm{~kW}$ need to be installed to supply $28.5 \mathrm{~kW}$ demanded. Analysing the subgroups 9 and 10 shows that, it is possible that both have the same installed power $(150 \mathrm{~kW})$, equally two gasifiers with 100 and $50 \mathrm{~kW}$ were considered for both with the requested power of 128,4 and $142,7 \mathrm{~kW}$, respectively. The same happens for the cases of 6 and $7(100 \mathrm{~kW}), 11$ to $14(200 \mathrm{~kW}), 16$ and $17(250 \mathrm{~kW}), 18$ to $21(300 \mathrm{~kW}), 22$ to $24(350 \mathrm{~kW}), 25$ to $28(400 \mathrm{~kW}), 29$ to $31(450 \mathrm{~kW})$ and 32 to $35(500 \mathrm{~kW})$.

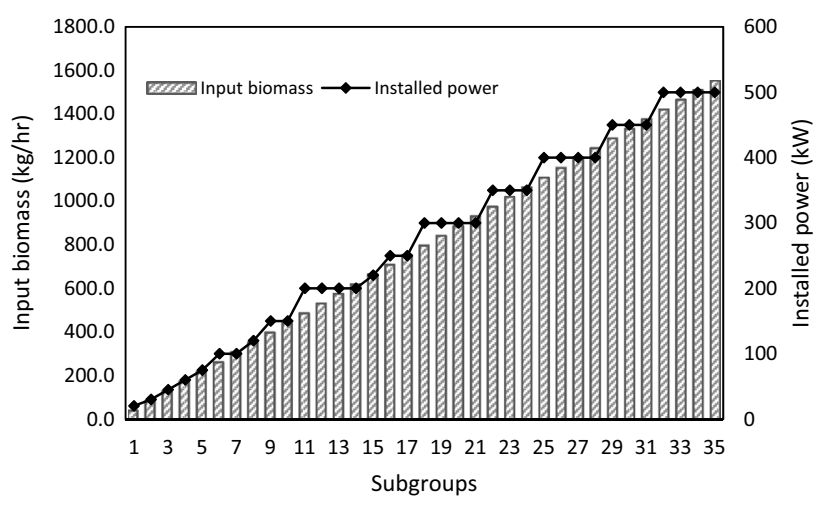

Fig. 4 Input T\&WW and installed power for subgroups

Figure 4 also shows the relation between the installed power and the amount of T\&WW that is fed to the system for treatment and power production. Clearly, the installed power does not increase in the same proportion as that of the input waste, due to different capacities used for each system. For some cases, the installed gasification capacities are oversized, so the required investments of the capital costs and O\&M costs need to be considered depending on the size of the components.

\section{Economic Assessment}

\section{Costs and Revenues}

The total cost of the generation plant for each population subgroup for the basic scenario (scenario 1) is shown together with the corresponding installed power in Fig. 5. The total cost varies from about $1100 \mathrm{k} €$ (Subgroup 1) to more than $2000 \mathrm{k} €$ (Subgroup 35). The total cost increases as the installed power grows, this trend is kept till up 5, but subgroups 6 and 7 present relatively lower cost in comparison to the former subgroup. It can be explained that the requested power of these subgroups $(100 \mathrm{~kW})$ are met only by using one gasifier. This is also similar for the subgroups of 11-14 (200 kW), 18-21 (300 kW), 25-28 (400 kW) and $32-35(500 \mathrm{~kW})$.

Percentage shares depicted in Fig. 6 are contributions of hardware, installation, engineering and annual O\&M costs in total cost for basic scenario. The yearly O\&M costs occupy 


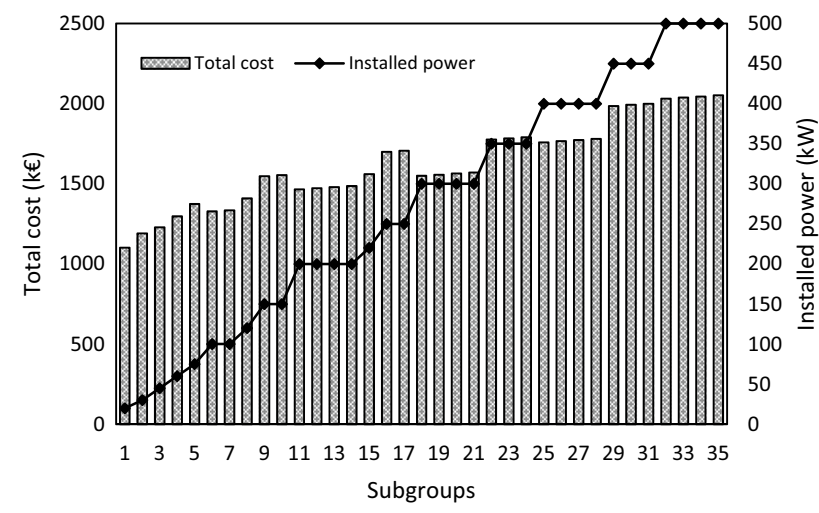

Fig. 5 Total costs on the basis of the installed power for scenario 1

more than $70 \%$ of total cost for the first subgroup, it has also the dominant statue among different kinds of costs for subgroups $1-8$. However, the highest share is related to gasification system price for subgroups 9-35.

Figure 7 presents the specific cost for the implantation of new facilities for power production by using T\&WW gasification, per ton of waste treated. It has been pointed out that the specific cost per ton of $\mathrm{T} \& \mathrm{WW}$ is inversely proportional to the installed capacity, at higher installed capacity lower the specific costs. Figure 7 also shows the specific costs per capita, indicating that for lower population, higher cost per inhabitant is required.

If decision makers want to implement the gasification technology in Icelandic cities, a viable solution for the subgroups 1-5 to reduce the specific costs could be to make connection between neighbour municipalities by making commons investments for bigger gasification facilities, where the T\&WW of two or three municipalities could be gasified together.

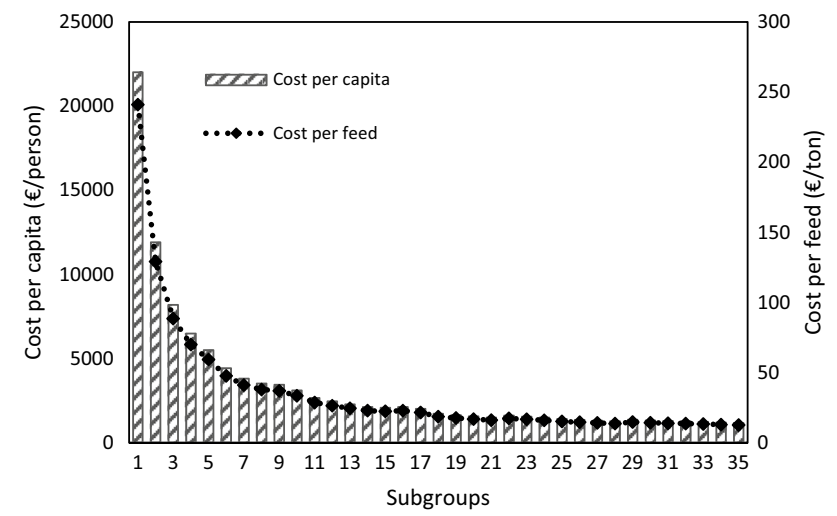

Fig. 7 Specific cost of T\&WW gasification per input waste and per capita

Regarding revenues, they are obtained by commercialization the generated electricity through the T\&WW gasification and the WTB fee for the treatment and disposal of T\&WW. Table 5 shows the revenues of the sale of electricity, the WTB fee and total revenue for each subgroup. The revenues have a direct relation with the amount of T\&WW production and treated per year, since the higher the input waste, the higher the products. The amount of treated T\&WW varies from 304.5 ton/year (subgroup 1) to $10,851.5$ ton/year (subgroup 35 ).

Selling of electricity varies from $12.5 \mathrm{k} €$ (subgroup 1) to $437.5 \mathrm{k} €$ (subgroup 35) and the gains because of WTB fees for the T\&WW treatment, range from $39.6 \mathrm{k} €$ (subgroup 1) to $1410.7 \mathrm{k} €$ (subgroup 35). It is worth mentioning that for all subgroups, the incomes obtained with the WTB fee are equivalent to more than $70 \%$ of total revenues.
Fig. 6 Percentage shares of total cost for scenario 1

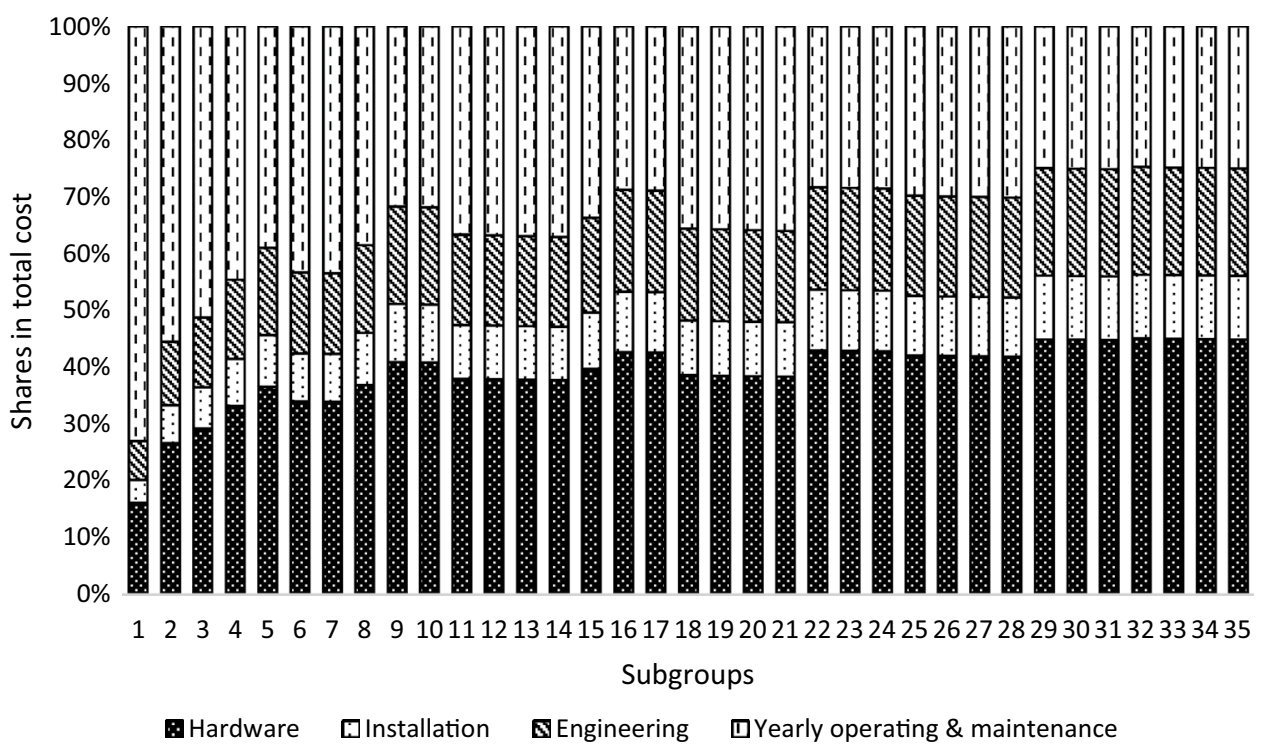


Table 5 The annual revenue based on sale of electricity and waste treated

\begin{tabular}{|c|c|c|c|c|c|c|c|}
\hline Subgroups & $\begin{array}{l}\text { Income with sale of } \\
\text { electricity ( } k \text { /year) }\end{array}$ & $\begin{array}{l}\text { Income with } \\
\text { WTB (k€/year) }\end{array}$ & $\begin{array}{l}\text { Total income } \\
\text { (k€/year) }\end{array}$ & Subgroups & $\begin{array}{l}\text { Income with sale of } \\
\text { electricity ( } k € / \text { year) }\end{array}$ & $\begin{array}{l}\text { Income with } \\
\text { WTB (k€/year) }\end{array}$ & $\begin{array}{l}\text { Total } \\
\text { income }(\mathrm{k} € / \\
\text { year) }\end{array}$ \\
\hline 1 & 12.50 & 39.59 & 52.09 & 19 & 237.50 & 765.47 & 1002.97 \\
\hline 2 & 25.00 & 79.91 & 104.91 & 20 & 250.00 & 805.79 & 1055.79 \\
\hline 3 & 37.50 & 120.24 & 157.74 & 21 & 262.50 & 846.12 & 1108.62 \\
\hline 4 & 50.00 & 160.57 & 210.57 & 22 & 275.00 & 886.44 & 1161.44 \\
\hline 5 & 62.50 & 200.89 & 263.39 & 23 & 287.50 & 926.77 & 1214.27 \\
\hline 6 & 75.00 & 241.22 & 316.22 & 24 & 300.00 & 967.10 & 1267.10 \\
\hline 7 & 87.50 & 281.55 & 369.05 & 25 & 312.50 & 1007.42 & 1319.92 \\
\hline 8 & 100.00 & 321.87 & 421.87 & 26 & 325.00 & 1047.75 & 1372.75 \\
\hline 9 & 112.50 & 362.20 & 474.70 & 27 & 337.50 & 1088.08 & 1425.58 \\
\hline 10 & 125.00 & 402.53 & 527.53 & 28 & 350.00 & 1128.40 & 1478.40 \\
\hline 11 & 137.50 & 442.85 & 580.35 & 29 & 362.50 & 1168.73 & 1531.23 \\
\hline 12 & 150.00 & 483.18 & 633.18 & 30 & 375.00 & 1209.06 & 1584.06 \\
\hline 13 & 162.50 & 523.51 & 686.01 & 31 & 387.50 & 1249.38 & 1636.88 \\
\hline 14 & 175.00 & 563.83 & 738.83 & 32 & 400.00 & 1289.71 & 1689.71 \\
\hline 15 & 187.50 & 604.16 & 791.66 & 33 & 412.50 & 1330.04 & 1742.54 \\
\hline 16 & 200.00 & 644.49 & 844.49 & 34 & 425.00 & 1370.36 & 1795.36 \\
\hline 17 & 212.50 & 684.81 & 897.31 & 35 & 437.50 & 1410.69 & 1848.19 \\
\hline 18 & 225.00 & 725.14 & 950.14 & & & & \\
\hline
\end{tabular}

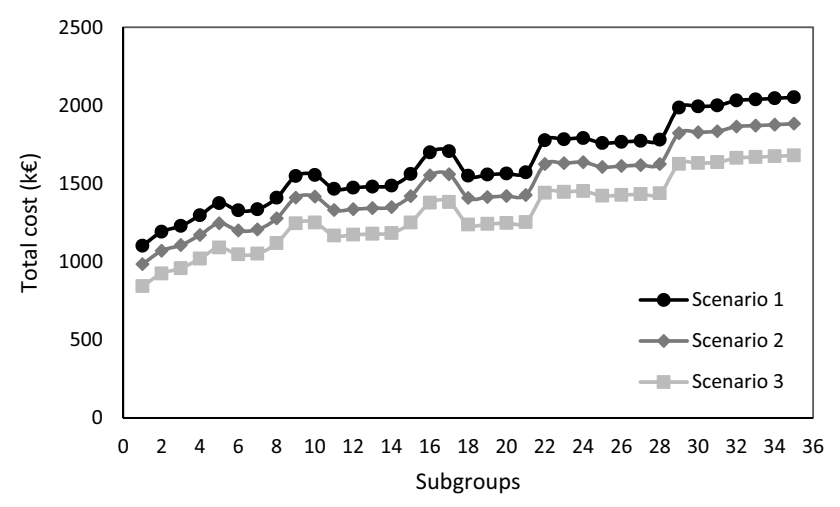

Fig. 8 Total costs for different scenarios

\section{Economic Assessment of Three Scenarios}

To have a comparison between different scenarios, the total costs required for power generation based on T\&WW gasification, during the period of analysis, for each subgroup are shown together in Fig. 8. Higher interest rates tend to reduce total cost during 15 years of operation. The total costs are as follows, with the interest rate of $8 \%$ for Scenario 1 range of $1100 \mathrm{k} €$ (subgroup 1) to $2050 \mathrm{k} €$ (subgroup 35), the costs with interest rate of $10 \%$ for Scenario 2 range of $983 \mathrm{k} €$ (subgroup 1) to $1882 \mathrm{k} €$ (subgroup 35), and total costs with interest rate of $13 \%$ for Scenario 3 range of $842 \mathrm{k} €$ (subgroup 1) to $1680 \mathrm{k} €$ (subgroup 35). In fact, for the higher interest rate, the smaller present investment is required to achieve the revenue required for the project to succeed. However, the costs alone do not reflect economic-effectiveness of the project. The costs, revenues and their effects together on NPV need to be investigated to demonstrate which project is the most beneficial from the economic perspectives.

The economic assessments, based on the indexes of NPV and DPP for scenarios 1, 2 and 3, are shown in Figs. 9, 10 and 11, respectively. Different from the discount rate, NPVs for three scenarios are positive in $94 \%$ of the subgroups (3-35) and negative in the remaining 6\% (1 and 2). In other words, implementation of T\&WW gasification integrated with power generation unit in Iceland could be economic beneficial projects for places with more than 150 inhabitants or for installed capacities higher than $45 \mathrm{~kW}$. It is worth noting that, in scenario 1 with the interest rate of $8 \%$, NPV is averagely $11 \%$ and $25 \%$ greater than scenarios 2 and 3, respectively.

In addition, changing the interest rate does not have significant impact on DPP for all studied scenarios; it is lower than 2 years in $88 \%$ of the subgroups (5-35) and attractively it is lower than 6 months from subgroup 13 reducing to 4 months for subgroup 35 . These all show that employing small-scale T\&WW gasification could be an economic alternative in Icelandic municipalities.

The subgroups that do not show economic feasibility for these scenarios could have the strategy of merging in municipalities to reduce the costs and increasing the yields, then 
Fig. 9 Economic analysis for scenario 1

Fig. 10 Economic analysis for scenario 2

Fig. 11 Economic analysis for scenario 3
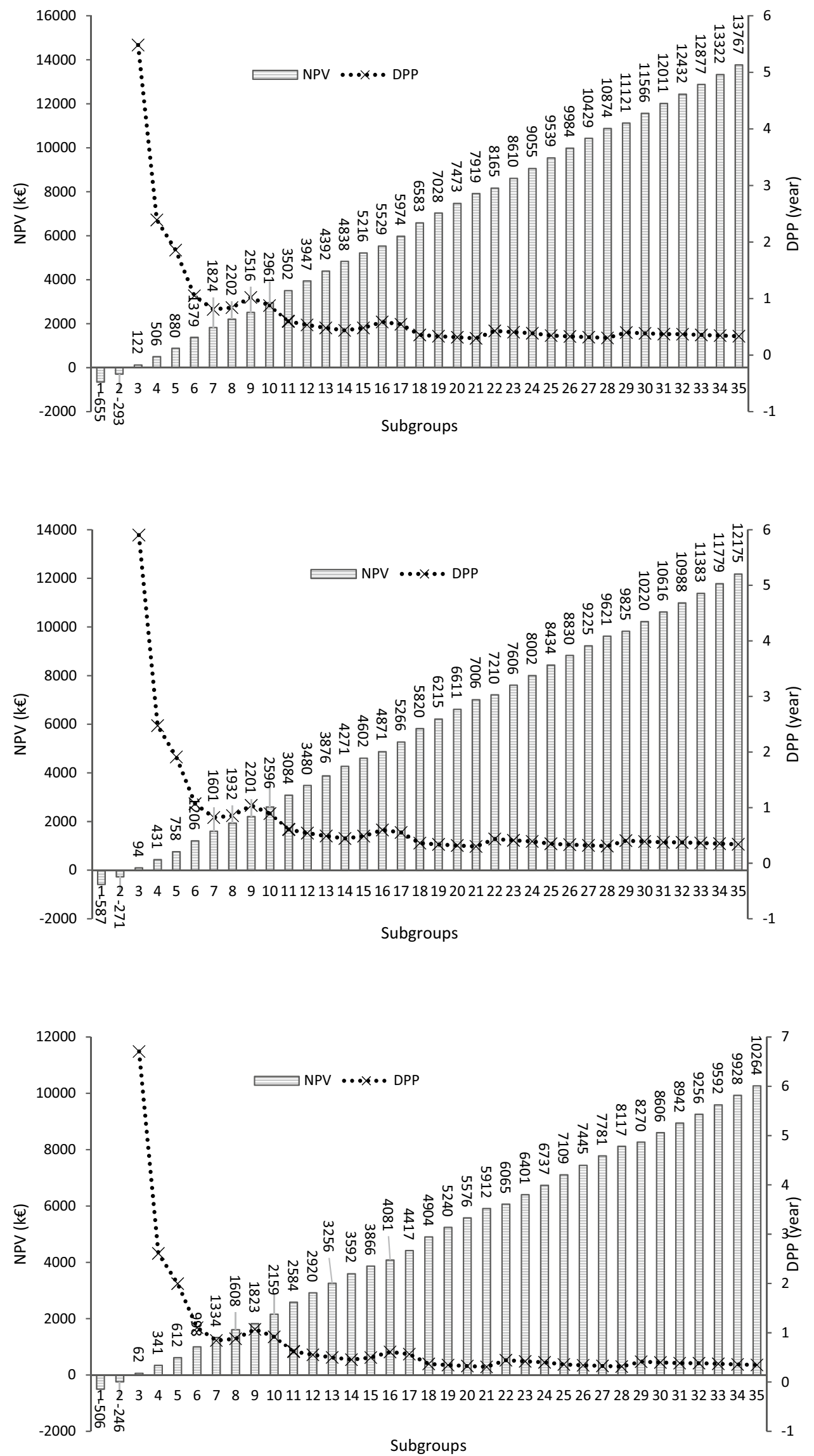
looking after the possibility of a higher amount of waste and making viable to install a treatment facility. Another way is to establish a minimum value for the fee of waste collection and disposing. Hence, it was carried out a sensitivity analysis, to find the minimum WTB, to have viable installation of a hypothetical T\&WW gasification plant, independent of its size (Table 6). The minimum WTB varies from about $380 €$ per ton of waste (subgroup 1) for all scenarios to zero from subgroup 14 in scenario 1 , subgroup 15 in scenario 2 and subgroup 17 in scenario 3 . In other words, in places with more than 700 inhabitants or with the higher installed capacity of $200 \mathrm{~kW}$, projects could be run economically without receiving any fee for collection and disposal of waste.

\section{Environmental Assessment}

The environmental impact assessment of timber and wood waste gasification integrated with power production unit is analysed with three categories of global warming, acidification and eutrophication potentials. tonCOThe GWP of T\&WW gasification for 35 studied subgroups and average GWP contributions through the gasifying are shown in Fig. 12. It is clear that as the household numbers/population grow, the electricity consumptions increase, therefore greenhouse gas emissions (GHG) are increased. The GHG emitted through T\&WW gasification is around 13 tonCO $\mathrm{CO}_{2 \mathrm{eq}}$ (Subgroup 1) to $469_{2 e q}$ (Subgroup 35), yearly.

The largest contribution in GWP is made by transport through the consumption of the diesel fuel following with gasifier in conversion step and cutting, handling and drying in the preparation process. Of the process in the chain, conversion 2 containing combustion chamber, gas and steam turbines occupies the smallest share in GWP contributions because when biomass is burnt, carbon dioxide releases back to the atmosphere but this biogenic $\mathrm{CO}_{2}$ is not counted as a contributor to global warming.

The acidification and eutrophication impacts for T\&WW gasification for all studied cases are shown in Fig. 13. Regarding AP index, production of electricity from timber and wood waste gasification creates 173.6 tonSO $_{2 \text { eq }}$ (Sub-

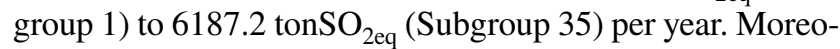
ver, electricity generation through the T\&WW gasification releases 331.9 tonNO $\mathrm{Neq}_{3 \text { (Subgroup 1) to } 11,827.7 \text { tonNO }}$ eq (Subgroup 35), annually. The most important contribution for AP and EP impacts is made by the emissions of particulate matters through the transport sector, following by pre-process and conversions steps (Fig. 13).

\section{Conclusions}

In this paper, power supply chain by using timber and wood waste gasification has been analysed and assessed from the technical, economic and environmental perspectives. The technical assessment focused mainly on input waste, installed power, and electrical power generation. The economic assessment conducted relied on the economic indicators of total cost, specific costs, revenues, NPV and DPP, bringing together three different economic scenarios, with interest rates of $8 \%$ for Scenario $1,10 \%$ for Scenario 2 and 13\% for Scenario 3. Additionally, a sensitivity analysis was carried out, to investigate the effects
Table 6 Minimum WTB for treatment of T\&WW to get a NPV more than zero

\begin{tabular}{llll}
\hline \multicolumn{3}{l}{ Minimum WTB (k€/ton) } & \\
\cline { 2 - 4 } Subgroup & Scenario 1 & Scenario 2 & Scenario 3 \\
\hline 1 & 0.381 & 0.384 & 0.387 \\
2 & 0.186 & 0.188 & 0.192 \\
3 & 0.115 & 0.117 & 0.120 \\
4 & 0.082 & 0.084 & 0.087 \\
5 & 0.063 & 0.065 & 0.069 \\
6 & 0.043 & 0.045 & 0.047 \\
7 & 0.032 & 0.033 & 0.035 \\
8 & 0.026 & 0.027 & 0.029 \\
9 & 0.025 & 0.026 & 0.029 \\
10 & 0.018 & 0.020 & 0.022 \\
11 & 0.010 & 0.011 & 0.013 \\
12 & 0.006 & 0.007 & 0.008 \\
13 & 0.003 & 0.003 & 0.005 \\
14 & From 14 to 35 is zero & 0.001 & 0.002 \\
15 & & From 15 to 35 is zero & 0.001 \\
16 & & & 0.003 \\
17 & & & From 17 to 35 is zero \\
\hline
\end{tabular}


Fig. 12 GWP of T\&WW gasification for electricity production and GWP contributions
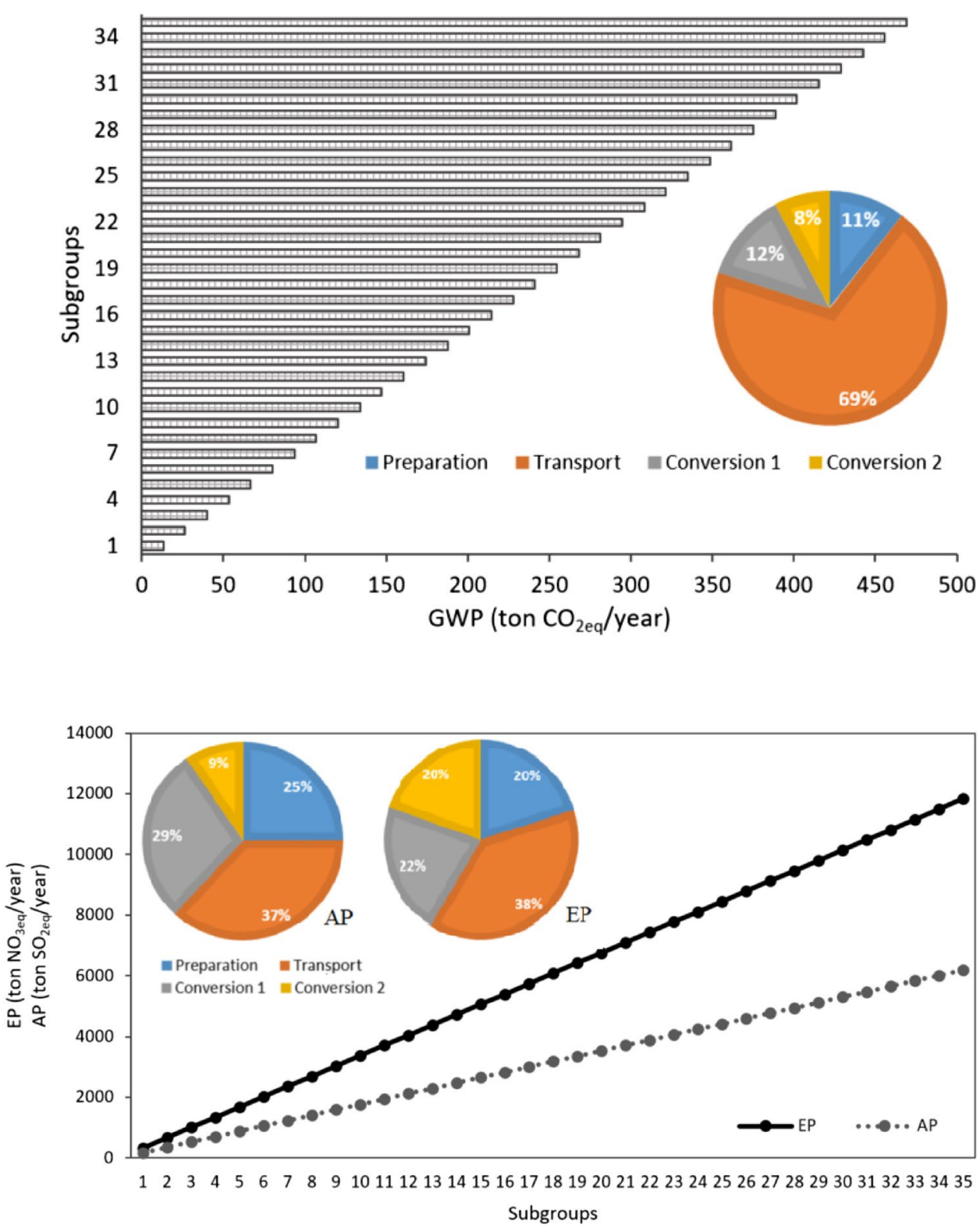

Fig. $13 \mathrm{AP}$ and $\mathrm{EP}$ of T\&WW gasification for electricity production, AP and EP contributions of the fee paid by the Icelandic municipalities for collection and disposal of wastes (WTB). The environmental analysis was also directed based on the environmental impacts of global warming, acidification and eutrophication potentials.

We clustered Icelandic municipalities with population lower than 2000 to 35 subgroups based on various number of households/inhabitants. In each subgroup, the study was conducted over hypothetical cases, according to the number of households as each household includes five persons. The costs of equipment, installation, engineering, operation and maintenance and the interest rate of the investment were considered. Regarding revenues, they come from of the electricity sale and the fee paid by the Icelandic municipalities for collection and disposal of waste.
The results show that changing the interest rate does not have significant impact on NPV and DPP for all studied scenarios. The NPV is positive for the municipalities with more than 30 households/150 inhabitants or for a hypothetic gasification plant with the capability to generate greater than $45 \mathrm{~kW}$ (for subgroups 3-35). The NPV in scenario 1 ( $8 \%$ for interest rate) is averagely 11 and $25 \%$ higher than scenarios 2 and 3, respectively. Moreover, for all studied scenarios, DPP is lower than 2 years in $88 \%$ of the subgroups as well as lower than 6 months for $60 \%$ of them.

The economic assessment could be also feasible for subgroups (1 and 2), because the WTB fee paid by the Icelandic municipalities for collection and disposal of waste and the quantity of waste can be adjusted. They also can merge together for making viable to install a treatment facility. 
Regarding environmental assessment, electricity generation based on T\&WW gasification would lead to a GWP of 13 tonCO $\mathrm{CO}_{2 \mathrm{eq}}$ (Subgroup 1) to 469 tonCO $\mathrm{CO}_{2 \mathrm{eq}}$ (Subgroup 35), AP of 173.6 tonSO $\mathrm{Seq}_{2 \mathrm{eq}}\left(\right.$ Subgroup 1) to 6187.2 ton $\mathrm{SO}_{2 \mathrm{eq}}$ (Subgroup 35), and EP potential of 331.9 tonNO $_{3 \text { eq }}$ (Sub-

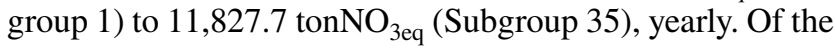
process in the chain, the largest contribution for all impacts is made by transport through the diesel fuel consumption following with gasifier in conversion step and cutting, handling and drying in preparation process.

Acknowledgements This paper was a part of the project funded by Icelandic Research Fund (IRF), (in Icelandic: Rannsoknasjodur) and the Grant Number is 196458-051.

\section{Compliance with Ethical Standards}

Conflict of interest All authors declare that they have no conflict of interest.

\section{References}

Brunner PH, Morf LS, Rechberger H (2004) Thermal waste treatmentA necessary element for sustainable waste management. na,

Chongqing Fengyu Electric Co. L (2019). https://feng-yu.com/.

Explained ES (2019) https://ec.europa.eu/eurostat/statistics-explained/ index.php?title=Electricity_and_heat_statistics\&oldid $=443526$. Acceseed 12 Dec, 2019

Freeman M, O'Dowda W, Plasynskia S, Walbertb G. Biomass cofiring $\mathrm{R} \& \mathrm{D}$ and demonstration results for handling, combustion, heat transfer, and emissions issues for coal-fired boilers. Carbon 55:48.47

GreenVinci Biomass Energy Co. L (2019) https://www.greenvinci .com/. Acceseed 12 Dec, 2019

Halldorsson TI, Auðunsson GA, Guicharnaud R, Dýrmundsson ÓR, Hansson SÖ, Hreinsson K Contamination of livestock due to the operation of a small waste incinerator: a case incident in Skutulsfjörður, Iceland, in 2010. In: Acta Veterinaria Scandinavica, 2012. vol 1. BioMed Central, p S4

Labs AP (2019) https://www.allpowerlabs.com/. Acceseed 12 Dec, 2019

Leckner B (2015) Process aspects in combustion and gasification Waste-to-Energy (WtE) units. Waste Manag 37:13-25

Luz FC, Rocha MH, Lora EES, Venturini OJ, Andrade RV, Leme MMV, del Olmo OA (2015) Techno-economic analysis of municipal solid waste gasification for electricity generation in Brazil. Energy Convers Manag 103:321-337

Mohapatra S (2013) Technological options for treatment of municipal solid waste of Delhi. Int J Renew Energy Res (IJRER) 3:682-687

Nguyen TLT, Hermansen JE, Nielsen RG (2013) Environmental assessment of gasification technology for biomass conversion to energy in comparison with other alternatives: the case of wheat straw. $\mathbf{J}$ Cleaner Prod 53:138-148

Niðurstöður úr mælingum á díoxínum í jarðvegi (2011). Umhverfisstofnun

Ofori-Boateng C, Lee KT, Mensah M (2013) The prospects of electricity generation from municipal solid waste (MSW) in Ghana: a better waste management option. Fuel Process Technol 110:94-102

Omari AM, Kichonge BN, John GR, Njau KN, Mtui PL (2014) Potential of municipal solid waste, as renewable energy source: a case study of Arusha, Tanzania. Int J Renew Energy Technol Res 3(6):1-9

Orkusetur (2019) https://orkusetur.is/reiknivelar/raforka/raforkuver d/. Accessed 12 Dec, 2019.

Paengjuntuek W, Boonmak J, Mungkalasiri J (2015) Environmental assessment of integrated biomass gasification fuel cell for power generation system. Int J Environ Sci Dev 6:445

Porcu A, Sollai S, Marotto D, Mureddu M, Ferrara F, Pettinau A (2019) Techno-economic analysis of a small-scale biomass-toenergy BFB gasification-based system. Energies 12:494

Porteous A (2005) Why energy from waste incineration is an essential component of environmentally responsible waste management. Waste Manag 25:451-459

Qingdao Kexin New Energy Technology.Co. L (2019) https://qdkexin.en.alibaba.com/. Accessed 02 Dec, 2019

Safarian S, Bararzadeh M (2012) Exergy analysis of high-performance cycles for gas turbine with air-bottoming. J Mech Eng Res 5:38-49

Safarian S, Khodaparast P, Kateb M (2014) Modeling and technicaleconomic optimization of electricity supply network by three photovoltaic systems. J Solar Energy Eng 136:024501

Safarian S, Richter C, Unnthorsson R (2019a) Waste biomass gasification simulation using aspen plus: performance evaluation of wood chips, sawdust and mixed paper wastes. J Power Energy Eng 7:12-30

Safarian S, Saboohi Y, Kateb M (2013) Evaluation of energy recovery and potential of hydrogen production in Iranian natural gas transmission network. Energy Policy 61:65-77

Safarian S, Sattari S, Hamidzadeh Z (2018) Sustainability assessment of biodiesel supply chain from various biomasses and conversion technologies. BioPhys Econ Resource Qual 3:6

Safarian S, Sattari S, Unnthorsson R, Hamidzadeh Z (2019b) Prioritization of bioethanol production systems from agricultural and waste agricultural biomass using multi-criteria decision making. Biophys Econ Resource Qual 4:4

Safarian S, Unnthorsson R (2018) An assessment of the sustainability of lignocellulosic bioethanol production from wastes in Iceland. Energies 11:1493

Safarian S, Unnthorsson R, Richter C (2019c) Performance analysis and environmental assessment of small-scale waste biomass gasification integrated CHP in Iceland. Energy. https://doi. org/10.1016/j.energy.2020.117268

Safarian S, Unnthorsson R, Richter C (2020a) Performance analysis and environmental assessment of small-scale waste biomass gasification integrated CHP in Iceland. Energy. https://doi. org/10.1016/j.energy.2020.117268

Safarian S, Unnthorsson R, Richter C (2020b) Simulation of smallscale waste biomass gasification integrated power production: a comparative performance analysis for timber and wood waste. Int J Appl Power Eng (IJAPE) 09:147-152

Safarian S, Unnthorsson R, Richter C (2020c) Simulation of smallscale waste biomass gasification integrated power production: a comparative performance analysis for timber and wood waste. Int J Appl Power Eng (IJAPE). https://doi.org/10.11591/ijape.v9. i2.pp $\% 25 \mathrm{p}$

Safarian S, Unnpórsson R, Richter C (2019d) A review of biomass gasification modelling. Renew Sustain Energy Rev 110:378-391

Safarianbana S, Unnthorsson R, Richter C (2019) Development of a new stoichiometric equilibrium-based model for wood chips and mixed paper wastes gasification by ASPEN Plus. In: ASME 2019 international mechanical engineering congress and exposition. American Society of Mechanical Engineers Digital Collection

Samadi SH, Ghobadian B, Nosrati M (2019) Prediction and estimation of biomass energy from agricultural residues using air gasification technology in Iran. Renew Energy. https://doi.org/10.1016/j. renene.2019.10.109 
Sara HR, Enrico B, Mauro V, Vincenzo N (2016) Techno-economic analysis of hydrogen production using biomass gasification-a small scale power plant study. Energy Procedia 101:806-813

Shandong Rotex Machinery. CL (2019) https://www.woodpellet s-machine.com/aboutus. Accessed 12 Dec, 2019

Sundberg M, Guðmundsson J, Guðmundsson M (2010) Biofuel production in Iceland: survey of potential raw materials and yields to 2030 Mannvit Engineering, Reykjavik
Tiger Machinery Group Co. L (2019) https://www.tigermg.com/. Accessed 02 Dec, 2019

Publisher's Note Springer Nature remains neutral with regard to jurisdictional claims in published maps and institutional affiliations. 